\title{
Anti-Staphylococcal Calopins from Fruiting Bodies of Caloboletus radicans
}

Fakir Shahidullah Tareq, ${ }^{\dagger}$, Choudhury Mahmood Hasan, ${ }^{\S}$ M. Mukhlesur Rahman, ${ }^{\#}$ Mohd

Mukrish Mohd Hanafi, ${ }^{\perp}$ Lucio Colombi Ciacchi, ${ }^{\nabla}$ Monika Michaelis, ${ }^{\nabla}$ Tilmann Harder, ${ }^{\circ}$, Jan Tebben, ${ }^{\Uparrow}$ Md. Tofazzal Islam, ${ }^{\phi}$ Peter Spiteller*,†

†University of Bremen, Faculty of Biology and Chemistry, Institute for Organic and Analytical Chemistry, NW2C, Leobener Straße 7, D-28359 Bremen, Germany

Department of Pharmacy, Manarat International University, Gulshan-2, Dhaka-1212, Bangladesh

${ }^{\S}$ Department of Pharmaceutical Chemistry, Faculty of Pharmacy, University of Dhaka, Dhaka 1000, Bangladesh

${ }^{\#}$ Medicine Research Group, School of Health, Sport and Bioscience, University of East London, Water Lane London E15 4LZ, United Kingdom

${ }^{\perp}$ School of Pharmacy, University College London, Gower St, Kings Cross, London WC1E 6BT, United Kingdom

${ }^{\nabla}$ University of Bremen, Faculty of Production Engineering, Leobener Straße UFT, D-28359 Bremen, Germany

${ }^{\circ}$ University of Bremen, Faculty of Biology and Chemistry, Leobener Straße 6, D-28359 Bremen, Germany

^Alfred Wegener Institute, Helmholtz Centre for Polar and Marine Research, Am Handelshafen 12, D-27570 Bremerhaven, Germany

$\Phi$ Department of Biotechnology, Bangabandhu Sheikh Mujibur Rahman Agricultural University, Dhaka-1000, Bangladesh. 
ABSTRACT: Three new and seven known calopins were isolated from Caloboletus radicans. The structures of the new cyclocalopins, 8-deacetylcyclocalopin B (1), cyclocalopin A-15-ol (2), and 12,15-dimethoxycyclocalopin A (3), were mainly elucidated by NMR and MS data analysis. The stereochemistry of 1-3 was assigned based on ROE correlations, coupling constants and by comparison of their CD spectra with those of similar known calopins. While 1-10 were inactive against two cancer cell lines, they displayed antistaphylococcal activity against methicillin-resistant Staphylococcus aureus strains (MRSA) with MIC values of 16-256 $\mu \mathrm{g} / \mathrm{mL}$. Moreover, some calopins were active against the fish pathogen Enterococcus faecalis F1B1. 
Antibiotic resistance is one of the major challenges of today's global public health. Bacteria resistant to antibiotics are described as "nightmare bacteria" by the World health leaders that "pose a catastrophic threat" to people in every country in the World. ${ }^{1}$ Among the antibiotic resistant pathogens, methicillin-resistant strains of Staphylococcus aureus (MRSA) are spreading worldwide within hospitals, extended care facilities and the community at large. Examples of infections caused by MRSA include respiratory, skin, soft tissue, bone, joints and urinary tract infections, endocarditis, acute osteomyelitis, meningitis, neonatal liver abscesses, epidural abscesses, mastitis, toxic shock syndrome, and even chorioamnionitis. ${ }^{2}$ According to a recent report, more than $25 \%$ of $S$. aureus infections in Europe are caused by MRSA. ${ }^{3}$ MRSA is contagious and can be spread through direct or indirect contact with an infected person. The treatment of these infections is expensive, problematic and time consuming. Moreover, long-term antibiotic medication to treat bacterial infections causes numerous side effects. ${ }^{4}$ These facts indicate the urgency to discover sufficiently active new natural scaffolds for the development of antibiotics with less or no side effects. It is well known that nature produces an amazing variety and number of compounds, which are both a fundamental source of new chemical diversity and an integral component of today's pharmaceutical compendium. ${ }^{5-7}$ However, readily available sources of natural products are often well investigated. Therefore, our search for new bioactive natural products is focused on mushrooms which are not easily accessible, since they usually cannot be cultivated and only occur temporarily in their natural environment. ${ }^{8,9}$ This also applies to Caloboletus radicans (Pers.) Vizzini, (= Boletus radicans Pers.: Fr., German name: Wurzelnder Bitterröhrling). The German name of this species reveals that the fruiting bodies taste bitter and are consequently inedible. Several years ago the bitter taste of the fruiting bodies was attributed to the presence of the previously unknown calopins. ${ }^{10-12}$ Although even total syntheses of several calopins have been published, ${ }^{13-15}$ there are no reports on the bioactivity 
of the calopins. The free radical-scavenging activity against $\mathrm{DPPH},{ }^{16,17}$ superoxides, ${ }^{17}$ and $\mathrm{PABS}^{17}$ radicals has been reported.

In this manuscript, we describe the isolation and structure elucidation of new (1-3) and previously reported calopins (4-10) from fruiting bodies of $C$. radicans which turned out to exhibit anti-staphylococcal activity and activity against fish-pathogenic bacteria.

Fractionation of the $\mathrm{MeOH}-\mathrm{H}_{2} \mathrm{O}$ extract from freeze-dried defatted fruiting bodies of $C$. radicans by first partitioning with $\mathrm{n}$-hexane and EtOAc, followed by repeated reversed-phase HPLC of the EtOAc soluble material with a subsequent $\mathrm{MeCN}-\mathrm{H}_{2} \mathrm{O}$ gradient and $\mathrm{MeOH}-\mathrm{H}_{2} \mathrm{O}$ isocratic eluents yielded three new cyclocalopin derivatives $\mathbf{1}-\mathbf{3}$ and seven previously known calopins $\mathbf{4 - 1 0}$.

The known calopins were identified as cyclopinol (4), cyclocalopin B (5), cyclocalopin A (6), 15-methoxycyclocalopin A (7), cyclocalopin E (8), calopin (9) and $O$-acetylcalopin (10) by comparison of their ${ }^{1} \mathrm{H}$ NMR, ${ }^{13} \mathrm{C}$ NMR, ESIMS and $\mathrm{CD}$ data to those reported previously. ${ }^{10-12}$

The molecular formula $\mathrm{C}_{17} \mathrm{H}_{24} \mathrm{O}_{7}$ of $\mathbf{1}$ was deduced by high-resolution ESIMS of the pseudomolecular ion. Seventeen carbon resonances were observed in the ${ }^{13} \mathrm{C}$ NMR spectrum which were assigned with the help of the HSQC spectrum to one ester carbonyl group at $\delta_{\mathrm{C}}$ $173.9 \mathrm{ppm}$, one acetyl carbon at $\delta_{\mathrm{C}} 176.0 \mathrm{ppm}$, two $\mathrm{sp}^{2}$ carbons at $\delta_{\mathrm{C}} 133.3$ and $123.1 \mathrm{ppm}$, two oxygenated methane carbons at $\delta_{\mathrm{C}} 71.9$ and $77.5 \mathrm{ppm}$, one oxygenated carbon with acetyl group at $\delta_{\mathrm{C}} 73.5 \mathrm{ppm}$, one oxygenated methylene carbon at $\delta_{\mathrm{C}} 72.9 \mathrm{ppm}$, one oxygenated quaternary carbon at $\delta_{\mathrm{C}} 108.3 \mathrm{ppm}$, one methylene carbon at $\delta_{\mathrm{C}} 27.2 \mathrm{ppm}$, two methine carbons at $\delta_{\mathrm{C}} 30.3$ and $47.1 \mathrm{ppm}$, one quaternary carbon at $\delta_{\mathrm{C}} 52.9 \mathrm{ppm}$ and four methyl carbons at $\delta_{\mathrm{C}} 14.6,17.5,19.5$ and $21.1 \mathrm{ppm}$. Based on these observations, the planar structure of 1 was established with the help of COSY, HMBC and ROESY correlations (Figure 1). A comparison of the NMR data of $\mathbf{1}$ with those of the known compound $\mathbf{5}$ 
revealed that $\mathbf{1}$ is structurally closely related to $\mathbf{5 .}{ }^{10}$ The new calopin (1) differs from compound $\mathbf{5}$ by the absence of one of the two acetyl groups of $\mathbf{5}$. The acetyl group of $\mathbf{1}$ was shown to be attached to $\mathrm{C}-7$ by an $\mathrm{HMBC}$ correlation of $\mathrm{H}-7$ at $\delta_{\mathrm{H}} 5.07 \mathrm{ppm}$ to the acetyl carbon at $\delta_{\mathrm{C}} 173.9 \mathrm{ppm}$ (Figure 1). The coupling constants in the ${ }^{1} \mathrm{H}$ NMR and the CD data of $\mathbf{5}^{10}$ are similar to those of $\mathbf{1}$. Furthermore, the NOE correlations (Figure 1) of H-3 with H-8, of H-7 with H-13, and of H-11 $\alpha$ with $\mathrm{H}-14$ in the NOESY spectrum of 1 indicate that 8deacetylcyclocalopin B (1) has the same configuration as cyclocalopin B (5).

The molecular formula of 2 was determined to be $\mathrm{C}_{15} \mathrm{H}_{20} \mathrm{O}_{7}$ by high-resolution ESIMS of the pseudomolecular ion. The ${ }^{1} \mathrm{H}$ and ${ }^{13} \mathrm{C}$ NMR data (Table 1) in combination with the molecular formula indicated that $\mathbf{2}$ is structurally closely related to cyclocalopin A (6). ${ }^{10}$ Instead of the methyl group present in $\mathbf{6}, \mathbf{2}$ bears a $\mathrm{CH}_{2} \mathrm{OH}$ group at $\mathrm{C}-9$. The position of the $\mathrm{CH}_{2} \mathrm{OH}$ group at $\mathrm{C}-9$ was deduced from the $\mathrm{HMBC}$ correlations of $\mathrm{H}-10$ at $\delta_{\mathrm{H}} 6.96$ ppm with the methylene carbon $\mathrm{C}-15$ at $\delta_{\mathrm{C}} 60.2 \mathrm{ppm}$, and of $\mathrm{H}-15$ at $\delta_{\mathrm{H}} 4.30 \mathrm{ppm}$ with the carbonyl carbon C-8 at $\delta_{\mathrm{C}} 199.3 \mathrm{ppm}$ (Figure 1). Due to the observed NOE correlations (Table 1), nearly identical coupling constants, and CD spectra cyclocalopin A-15-ol (2) possesses the same configuration as $\mathbf{6}$.

The molecular formula $\mathrm{C}_{17} \mathrm{H}_{24} \mathrm{O}_{7}$ of $\mathbf{3}$ was derived from the pseudomolecular ion in the high-resolution ESIMS in combination with ${ }^{1} \mathrm{H}$ and ${ }^{13} \mathrm{C}$ NMR data. The ${ }^{1} \mathrm{H}$ and ${ }^{13} \mathrm{C}$ NMR data (Table 1) of $\mathbf{3}$ are very similar to those of 15 -methoxycyclocalopin A (7). ${ }^{12}$ Compound 3 differs from 7 only in respect of the presence of two broad singlets at $\delta_{\mathrm{H}} 3.17$ and $3.36 \mathrm{ppm}$ instead of one, revealing that $\mathbf{3}$ possesses two methoxy groups. One $\mathrm{CH}_{3} \mathrm{O}$ - group is attached at $\mathrm{C}-12$ due to $\mathrm{HMBC}$ correlations of $\mathrm{H}-17$ at $\delta_{\mathrm{H}} 3.17$ ppm with the anomeric carbon $\mathrm{C}-12$ at $\delta_{\mathrm{C}} 110.9 \mathrm{ppm}$ and with the carbon $\mathrm{C}-6$ at $\delta_{\mathrm{C}} 56.7 \mathrm{ppm}$ (Figure 1). The second $\mathrm{CH}_{3} \mathrm{O}$ - group is located at C-15 as shown by the HMBC correlation of $\mathrm{H}-16$ at $\delta_{\mathrm{H}} 3.36 \mathrm{ppm}$ with the methylene carbon C-15 at $\delta_{\mathrm{C}} 68.6 \mathrm{ppm}$. The stereochemistry of 12,15-dimethoxycyclocalopin 
A (3) was assigned to be the same as that of 7 because of nearly identical coupling constants and CD data.

Calopins 1-10 $(100 \mu \mathrm{M})$ were inactive against PC3, prostate cancer and HepG2, liver hepatoblastoma cells. The activity of 1-10 against a panel of $S$. aureus strains, including the multidrug resistant (MDR) and methicillin-resistant Staphylococcus aureus (MRSA) strain SA-1199B that overproduces the NorA efflux pump and possesses a high level of resistance to some fluoroquinolones, ${ }^{18,19}$ the macrolide-resistant strain RN4220, ${ }^{20}$ the MRSA strain XU212 that is resistant to tetracycline, ${ }^{21}$ the standard laboratory strain ATCC $25923,{ }^{21}$ and the epidemic methicillin-resistant strain EMRSA-15 was evaluated. ${ }^{19}$ Calopins 1-10 displayed activity against SA-1199B but turned out to be inactive against the strain RN4220 (Table 2). Moreover, 1 was found to be more active than the positive control norfloxacin. ${ }^{19-22}$ against ATCC 25923 and SA-1199B with MICs of $16 \mu \mathrm{g} / \mathrm{mL}$. In general, compound 3 was found less active than the calopins $\mathbf{1}$ and $\mathbf{2}$. The reason might be the lack of a free hydroxy group at $\mathrm{C}$ 12.

Compounds 3, 5, 6, 9 and 10 were also tested against the phytopathogens Phytophthora capsici, a pathogen of several plants including peppers, ${ }^{23}$ Colletotrichum gloeosporioides strain CG12, a phytopathogen of strawberry, ${ }^{24}$ Magnaporthe oryzae Triticum pathotype strain $\mathrm{JP} 4{ }^{25}$ a wheat blast fungus, and against the two fish pathogenic Enterococcus faecalis strains $^{26}$ FF11 and F1B1. The tested compounds displayed varying levels of inhibitory effects against the strain F1B1 at $40 \mu \mathrm{g}$ /disk but were inactive against $C$. gloeosporioides, M. oryzae Triticum pathotype and E. faecalis strain FF11 up to $1000 \mu \mathrm{g} / \mathrm{ml}$. The inhibition zones around the disks were recorded to be $5.5 \pm 0.9$ for compound $\mathbf{3}, 5.5 \pm 1.0$ for $\mathbf{5}, 7.1 \pm 1.5$ for $\mathbf{6}, 5.6 \pm$ 1.3 for $\mathbf{9}$, and $9.5 \pm 1.2 \mathrm{~mm}$ for compound 10. Since the fish pathogenic E. faecalis strain F1B1 is highly resistant to several antibiotics such as amoxicillin, ampicillin, cefradine, cefuroxime, erythromycin and penicillin $\mathrm{G},{ }^{26}$ the calopins might be useful as lead structures 
for the development of agents for the control of fish pathogens.

\section{EXPERIMENTAL SECTION}

General Experimental Procedures. Extraction was performed in a 5 L Erlenmeyer flask with constant stirring using an IKA magnetic stirrer. Filtration was carried out with filter paper with a particle retention size of $12-15 \mu \mathrm{m}$. Organic solvents were evaporated under reduced pressure using a rotary evaporator (IKA) at room temperature $\left(26^{\circ} \mathrm{C}\right)$. A benchtop manifold freeze-drier from Christ was used to obtain completely $\mathrm{H}_{2} \mathrm{O}$ free samples. Semipreparative HPLC separation was performed on an HPLC system equipped with two Waters 590EF pumps, the automated gradient controller 680 and a Knauer UV/vis detector. Extracts from C. calopus were separated first on a $\mathrm{C}_{18}$ ec column (Nucleodur, $16 \times 250 \mathrm{~mm}, 5 \mu \mathrm{m}$, $100 \AA$, Macherey-Nagel) with the following gradient: Starting from $\mathrm{MeCN}-\mathrm{H}_{2} \mathrm{O}(+0.1 \%$ HOAc) (10:90) linear to $\mathrm{MeCN}-\mathrm{H}_{2} \mathrm{O}(+0.1 \%$ HOAc) (40:60) within 30 min, then within 20 min to $100 \% \mathrm{MeCN}$; flow rate $6 \mathrm{~mL} / \mathrm{min}$; UV detection at $250 \mathrm{~nm}$. A second separation step was performed on a $\mathrm{C}_{18} \mathrm{ec}$ column with a smaller diameter (Nucleodur, $10 \times 250 \mathrm{~mm}, 5 \mu \mathrm{m}$, $100 \AA$, Macherey-Nagel) with the following isocratic separation program: $\mathrm{MeOH}-\mathrm{H}_{2} \mathrm{O}$ (20:80); flow rate $3 \mathrm{~mL} / \mathrm{min}$; UV detection at $250 \mathrm{~nm}$. Optical rotations: Perkin-Elmer 243. CD: Applied Photophysics Chirascan ${ }^{\mathrm{TM}}$ CD spectrometer (1 mm cell). NMR: Bruker Avance DRX-600 ( ${ }^{1} \mathrm{H}$ NMR at $600.22 \mathrm{MHz},{ }^{13} \mathrm{C} \mathrm{NMR}$ at $\left.150.91 \mathrm{MHz}, 300 \mathrm{~K}\right)$, and Bruker Avance WB-360 $\left({ }^{1} \mathrm{H}\right.$ NMR at $360 \mathrm{MHz},{ }^{13} \mathrm{C} \mathrm{NMR}$ at $\left.91 \mathrm{MHz}, 300 \mathrm{~K}\right)$; chemical shifts in ppm are referenced to the residual solvent signal $\left(\mathrm{D}_{2} \mathrm{O}: \delta_{\mathrm{H}}=4.79 \mathrm{ppm} ; \mathrm{CDCl}_{3}: \delta_{\mathrm{H}}=7.26 \mathrm{ppm}, \delta_{\mathrm{C}}=\right.$ 77.0 ppm). LC-ESIMS spectra were obtained on an LCQ DecaXP Plus ESIMS spectrometer (Thermo Fisher Scientific Inc., USA). The spectrometer was operated in the positive mode (0.625 spectra $\mathrm{s}^{-1}$; mass range 50-1000). Nitrogen was used as sheath gas (80 arbitrary units) and helium served as collision gas. The spectrometer was equipped with a Hewlett-Packard 
HPLC system (Series 1100) consisting of a degasser, a pump system, a DAD detector, and an auto-sampler (injection volume $10 \mu \mathrm{L}$ ). The separations were performed with a $\mathrm{C}_{18}$ ec column (Nucleodur, $4.6 \times 250 \mathrm{~mm}, 5 \mu \mathrm{m}, 100 \AA$, Macherey-Nagel) using the following gradient program: Within the first 50 min linear from $\mathrm{MeCN}-\mathrm{H}_{2} \mathrm{O}(+0.1 \% \mathrm{HOAc})(10: 90)$ to $100 \%$ $\mathrm{MeOH}$, flow rate $0.66 \mathrm{~mL} / \mathrm{min}$. HR-ESIMS spectra of compounds $\mathbf{1}$ and $\mathbf{2}$ were recorded on a Finnigan MAT 95 high resolution, double focusing magnetic sector field mass spectrometer. Accurate mass measurements were achieved using the accelerating voltage of $5 \mathrm{kV}$, taurocholic acid as an internal standard, $\left([\mathrm{M}-\mathrm{H}]^{-}=514.2839\right)$, a resolution between 5000 and 10000 , and a scan range of 150 to $1000 \mathrm{~m} / \mathrm{z}$. The HR-ESIMS spectrum of compound 3 was acquired with a Q Exactive Plus mass spectrometer (Thermo Fisher Scientific, Bremen, Germany), using a heated electrospray ionization (HESI-II) source in positive mode at a flow-rate of $5 \mu \mathrm{L}$ per minute. MS measurement was performed in full MS mode with a resolution of 280,000, a scan range of 150 to $800 \mathrm{~m} / \mathrm{z}$ using a spray voltage of $3 \mathrm{kV}$.

Collection of Mushrooms. Fruiting bodies of $C$. radicans Pers.: Fr. (leg. et det. N. Arnold) were collected in September and October 1998 at Gerolfing in Bavaria, Germany and immediately frozen and stored at $-20{ }^{\circ} \mathrm{C}$. Voucher samples of $C$. radicans are deposited at the Institut für Organische und Analytische Chemie, Universität Bremen, Germany.

Extraction and Isolation. Frozen fruiting bodies of $C$. radicans $(2.0 \mathrm{~kg})$ were crushed and extracted with $2 \mathrm{~L}$ of $\mathrm{MeOH}-\mathrm{H}_{2} \mathrm{O}(1: 1 \mathrm{v} / \mathrm{v})$ (two times) with constant stirring at $200 \mathrm{rpm}$ and $25{ }^{\circ} \mathrm{C}$ for $1 \mathrm{~h}$. The supernatant was filtered, solvent was evaporated, residue re-dissolved in $\mathrm{MeOH}-\mathrm{H}_{2} \mathrm{O}(1: 4 \mathrm{v} / \mathrm{v})$ and partitioned between n-hexane and EtOAc. The solvents from nhexane $(\mathrm{Hx})$, EtOAc and $\mathrm{MeOH}-\mathrm{H}_{2} \mathrm{O}(\mathrm{MH})$ fractions were evaporated and subjected to an LC-MS and ${ }^{1} \mathrm{H}$ NMR analysis. The LC-MS and ${ }^{1} \mathrm{H}$ NMR data of the Hx and MH fractions clearly indicated the presence of fat and sugar, respectively, whereas the EtOAc fraction contained several classes of compounds including nucleosides. The EtOAc fraction (455.6 
$\mathrm{mg}$ ) was subjected to further purification. The EtOAc fraction was dissolved in methanol and filtered with a $\mathrm{C}_{18}$ ec cartridge. The supernatant was separated by HPLC first on an $\mathrm{C}_{18}$ ec column with $16 \mathrm{~mm}$ diameter, on an $\mathrm{C}_{18}$ ec column with $10 \mathrm{~mm}$ diameter. A $2 \mathrm{~kg}$ amount of fruiting bodies yielded $2.8 \mathrm{mg}$ of 8-deacetylcyclocalopin B (1), $2.3 \mathrm{mg}$ of cyclocalopin A-15ol (2), $5.3 \mathrm{mg}$ 12,15-dimethoxycyclocalopin A (3), $2.5 \mathrm{mg}$ of 4, $8.2 \mathrm{mg}$ of 5, $12.5 \mathrm{mg}$ of $\mathbf{6}$, $3.5 \mathrm{mg}$ of $\mathbf{7}, 1.8 \mathrm{mg}$ of $\mathbf{8}, 15.5 \mathrm{mg}$ of $\mathbf{9}$ and $22.8 \mathrm{mg}$ of $\mathbf{1 0 .}$

8-Deacetylcyclocalopin B (1): colorless oil; $\mathrm{HPLC}_{\mathrm{prep}}, t_{\mathrm{R}} 23.8 \mathrm{~min}$ (step 1), $30.5 \mathrm{~min}$ (step 2); LC-(+)-ESIMS $t_{\mathrm{R}} 24.5 \mathrm{~min} ;[\alpha]^{24}{ }_{\mathrm{D}}-0.21\left(c\right.$ 0.003, MeOH); UV/Vis $(\mathrm{MeOH}) \lambda_{\max } 256,268$, $274 \mathrm{~nm} ; \mathrm{CD}\left(\mathrm{CH}_{3} \mathrm{CN}\right) \lambda_{\max }(\Delta \varepsilon) 221(+0.77), 231(+0.38), 239(0), 251(-0.19), 271(-0.05)$ nm; ${ }^{1} \mathrm{H}$ and ${ }^{13} \mathrm{C}$ NMR (see Table 1); HR-(+)-ESIMS $m / z 363.1409[\mathrm{M}+\mathrm{Na}]^{+}$(calcd for $\left.\mathrm{C}_{17} \mathrm{H}_{24} \mathrm{O}_{7} \mathrm{Na}^{+}, 363.1419[\mathrm{M}+\mathrm{Na}]^{+}\right)$.

Cyclocalopin A-15-ol (2): amorphous solid, $\mathrm{HPLC}_{\mathrm{prep}}, t_{\mathrm{R}} 30.6 \mathrm{~min}$ (step 1), $35.5 \mathrm{~min}$ (step 2); LC-(+)-ESIMS $t_{\mathrm{R}} 30.9 \mathrm{~min} ;[\alpha]^{24}{ }_{\mathrm{D}}-46.5\left(c 0.05, \mathrm{CHCl}_{3}\right)$; $\mathrm{CD}(\mathrm{MeOH}) \lambda_{\max }(\Delta \varepsilon) 214(+3.69)$, $223(+1.55), 228(0), 243(-3.20), 253(-2.01), 323(+0.87) \mathrm{nm} ;{ }^{1} \mathrm{H}$ and ${ }^{13} \mathrm{C}$ NMR (see Table 1); HR-(-)-ESIMS $m / z 311.1135[\mathrm{M}-\mathrm{H}]^{-}$(calcd for $\mathrm{C}_{15} \mathrm{H}_{19} \mathrm{O}_{7}^{-}, 311.1131[\mathrm{M}-\mathrm{H}]^{-}$).

12,15-Dimethoxycyclocalopin A (3): amorphous solid, HPLC $\mathrm{prep}_{\mathrm{R}} 20.52 \mathrm{~min}$ (step 1), 22.30 $\min \left(\right.$ step 2); LC-(+)-ESIMS $t_{\mathrm{R}} 22.85 \mathrm{~min} ;[\alpha]^{24}{ }_{\mathrm{D}}+35.5\left(c \quad 0.01, \mathrm{CHCl}_{3}\right) ; \mathrm{CD}(\mathrm{MeOH}) \lambda_{\max }$ $(\Delta \varepsilon) 216(+4.95), 220(+0.55), 228(0), 243(-4.20), 323(+0.87) \mathrm{nm} ;{ }^{1} \mathrm{H}$ and ${ }^{13} \mathrm{C}$ NMR (see Table 1); HR-(+)-ESIMS m/z 363.1409 $[\mathrm{M}+\mathrm{Na}]^{+}$(calcd for $\mathrm{C}_{17} \mathrm{H}_{24} \mathrm{O}_{7} \mathrm{Na}^{+}, 363.1419[\mathrm{M}+$ $\left.\mathrm{Na}]^{+}\right)$.

Test for Anti-Staphylococcal Activity. The anti-MRSA activity of the compounds 1-10 was investigated with the standard MRSA strains ATCC 25923, XU212, SA-1199B, RN4220, and EMRSA-15 by a broth dilution assay. ${ }^{27}$ All five MRSA strains were incubated separately for $24 \mathrm{~h}$ at $37{ }^{\circ} \mathrm{C}$ on nutrient agar (Oxoid) and prepared for an inoculum density of $5 \times 10^{5}$ colony forming units in normal saline water $(9 \mathrm{~g} / \mathrm{L})$ by comparison with a 0.5 MacFarland turbidity 
standard. To avoid contamination, sterilized nutrient agar, saline water and Mueller-Hinton broth (MHB; Oxide) were used. The positive control (norfloxacin) was prepared by dissolving the antibiotic in DMSO (Sigma). After having all these requisites in hand, MHB was dispensed into 10 wells of a 96 well microtiter plate (Nunc, $0.3 \mathrm{ml}$ volume per well). The compounds 1-10 and antibiotic were serially diluted (over the range of concentrations $0.5-256 \mu \mathrm{g} / \mathrm{mL}$ ) into each of the wells followed by the addition of the bacterial inoculum, and the microtiter plate was incubated at $37^{\circ} \mathrm{C}$ for $18 \mathrm{~h}$. A DMSO control was included in all assays. The MIC recorded the lowest concentration at which no growth was observed. This was facilitated by the addition of $20 \mu \mathrm{L}$ of a $5 \mathrm{mg} / \mathrm{mL}$ methanolic solution of 3-[4,5dimethylthiazol-2-yl]-2,5-diphenyltetrazolium bromide (MTT; Sigma) to each of the wells and incubation for 20 minutes. Bacterial growth was indicated by a color change from yellow to dark blue. All MICs were determined independently at least three times.

Activity against Oomycetes and Fungi by a Disk Diffusion Method. ${ }^{28}$ To test the inhibitory activity of the compounds $3,5,6,9$ and 10, the oomycete Phytophthora capsici and the fungi Colletotrichum gloeosporioides and Magnaporthe oryzae triticum Pathotype were cultured on $10 \% \mathrm{~V} 8$ agar medium at $25{ }^{\circ} \mathrm{C}$ in the dark. ${ }^{29} \mathrm{~A} 4 \mathrm{~mm}$ diameter mycelia agar block was placed at the center of the PDA plate $(9 \mathrm{~cm})$. The compounds were dissolved in acetone and a stock solution of $1000 \mu \mathrm{g} / \mathrm{mL}$ was prepared. A $40 \mu \mathrm{L}$ sample of each stock solution was carefully applied onto a paper disk $(8 \mathrm{~mm})$ and allowed to dry. After evaporation of the solvent, the disk was placed $4 \mathrm{~mm}$ apart from the mycelia block of the pathogen and incubated at $25^{\circ} \mathrm{C}$ in the dark for 5 days. Then, the zone of inhibition was measured $(\mathrm{mm})$ for each sample against control strains. Each treatment was replicated three times.

Inhibitory Activity against Fish Pathogens by a Disk Diffusion Method. ${ }^{28}$ To test the antibacterial activity of compounds 3, 5, 6, 9 and $\mathbf{1 0}$ against Enterococcus faecalis strains FF11 and F1B1, bacterial suspensions $\left(1 \times 10^{5} \mathrm{CFU} / \mathrm{mL}\right)$ were spread on the agar plate. A 40 
$\mu \mathrm{L}$ sample of each compound (concentration $1000 \mu \mathrm{g} / \mathrm{mL}$ ) in acetone was carefully applied onto a paper disk $(8 \mathrm{~mm})$ and allowed to dry the solvent and then placed onto the $\mathrm{MH}$ agar plate. The inhibitory activity of the compound is displayed as bacteria free halo zone after 2 days of incubation at $37{ }^{\circ} \mathrm{C}$. The diameter of the halo zone was measured and the result was expressed as mean value \pm standard error of three replications of each dose of each compound. Antibiotic azithromycin was used as positive control.

Cytotoxicity Test (SRB Assay). The cancer cell growth inhibitory activity of the compounds 1-10 was evaluated by a sulforhodamine B (SRB) assay. ${ }^{30,31}$ In brief, prostate cancer (PC3) and liver hepatoblastoma (HepG2) cells were cultured in Dulbecco's Modified Eagle's Medium (DMEM) media supplemented with $10 \%$ fetal bovine serum and $1 \%$ penicillinstreptomycin (USA) and maintained at $37{ }^{\circ} \mathrm{C}$ in a humidified incubator with an atmosphere of $5 \% \mathrm{CO}_{2}$. The cells were seeded in 96-well microtiter plates in $100 \mu 1$ culture medium at cell concentration of $5 \times 10^{4}$ cells $/ \mathrm{mL}$. After an overnight adaptation period, the cells were treated with test compounds $\mathbf{1 - 1 0}$ in a $\mathrm{CO}_{2}$ incubator for $72 \mathrm{~h}$. When cells reached $70 \%$ confluence in a microtiter plate, the medium was replaced with DMEM 5\% FBS and incubated further $48 \mathrm{~h}$. Then, the medium was discarded, and cells were fixed by adding 50 $\mu \mathrm{L}$ of $10 \%$ trichloroacetic acid (TCA, Sigma-Aldrich Chemical, St. Louis, MO, USA). The cells were then incubated at $4{ }^{\circ} \mathrm{C}$ for $30 \mathrm{~min}$; TCA was drained off, and the plates were left to dry. Then, $50 \mu \mathrm{L}$ of SRB stain (10 mg of $1 \%$ acetic acid, Sigma) were added to each well for 30 min. Finally, the plates were washed four times with $1 \%$ acetic acid $(100 \mu \mathrm{L})$. The OD was measured at $540 \mathrm{~nm}$ using an ELISA reader (Bio-Rad). Paclitaxel was used as a positive control, whereas cells incubated only with $0.05 \%$ of DMSO were used as a negative control. All experiments were performed in triplicate. 


\section{ASSOCIATED CONTENT}

\section{Supporting Information Available:}

The Supporting Information is available free of charge on the ACS website at DOI:

Selected NMR and mass spectra of compounds 1, 2 and $\mathbf{3}$ and selected spectroscopic data of compounds 4-10. This material is available free of charge via the Internet at http://pubs.acs.org.

\section{AUTHOR INFORMATION}

\section{Corresponding Author}

* Tel: +49-421-218-63100. Fax: +49-421-218-63102. E-mail: peter.spiteller@uni-bremen.de.

\section{ORCID}

Peter Spiteller: 0000-0003-2916-4319

\section{Author Contributions}

The manuscript was written through contributions of all authors. All authors have given approval to the final version of the manuscript.

\section{Funding Sources}

Deutsche Forschungsgemeinschaft (SP718/4-1).

Alexander von Humboldt Foundation.

\section{Notes}

The authors declare no competing financial interest. 


\section{ACKNOWLEDGMENTS}

We are grateful to Dr. Norbert Arnold (Leibniz Institut für Pflanzenbiochemie, Halle an der Saale) for the collection and determination of the mushroom material, to J. Stelten and W. Willker (Institut für Organische und Analytische Chemie, Universität Bremen) for their support with NMR measurements, to Dr. Jose Prieto Garcia (Lecturer in Pharmacognosy, University College London, United Kingdom) for providing us the laboratory facility to carry out the cytotoxicity tests, to Jörg Albers (Arbeitskreis Pilzkunde im Naturwissenschaftlichen Verein zu Bremen) for a picture of $C$. radicans, to the Alexander von Humboldt Foundation for providing a Georg Forster Fellowship to F. S. Tareq and to the Deutsche Forschungsgemeinschaft (SP718/4-1) for financial support. 


\section{REFERENCES}

(1) Ballal, M. Trends in Antimicrobial Resistance Among Energetic Pathogens: A Global

Concern. In Antibiotic Resistance: Mechanisms and New Antimicrobial Approaches; Kon, K.; Rai, M., Ed.; Academic Press: London 2016; Chapter 4, p 63-89.

(2) Waness, A. J. Glob. Infect. Dis. 2010, 2, 49-56.

(3) Steenbergen, J. N.; Alder, J.; Thorne, G. M.; Tally, F. P. J Antimicrob. Chemother. 2005, $55,283-288$.

(4) Jernberg, C.; Lofmark, S.; Edlund, C.; Jansson, J. K. Microbiology 2010, 156, 3216-3223.

(5) Newman, D. J.; Cragg, G. M. J. Nat. Prod. 2016, 79, 629-661.

(6) Demain, A. L. Appl. Microbiol. Biotechnol. 1999, 52, 455-463.

(7) Fenical, W.; Jensen, P. R. Nat. Chem. Biol. 2006, 2, 666-673.

(8) Spiteller, P. Nat. Prod. Rep. 2015, 32, 971-993.

(9) Spiteller, P. Chem. Eur. J. 2008, 14, 9100-9110.

(10) Hellwig, V.; Dasenbrock, J.; Graf, C.; Kahner, L.; Schumann, S.; Steglich, W. Eur. J. Org. Chem. 2002, 2895-2904.

(11) Liu, D.-Z.; Wang, F.; Jia, R.-R.; Liu, J.-K. Z. Naturforsch. B, 2008, 63b, 114-116.

(12) Steglich, W.; Hellwig, V. Org. Lett. 2004, 6, 3175-3177.

(13) Ebel, H.; Knor, S.; Steglich, W. Tetrahedron 2003, 59, 123-129.

(14) Ebel, H.; Zeitler, K.; Steglich, W. Synthesis 2003, 1, 101-106.

(15) Nelson, S. G.; Wang, K., J. Am. Chem. Soc. 2006, 128, 4232-4233.

(16) Kim, W.-G.; Kim, J.-W.; Ryoo, I.-J.; Kim, J.-P.; Kim, Y.-H.; Yoo, I.-D. Org. Lett. 2004, 6, 823-826 (Remark: see reference 12 for the correct structures).

(17) Kim, J.-W.; Yoo, I.-D.; Kim, W.-G. Planta Med. 2006, 72, 1431-1432.

(18) Kaatz, G. W.; Seo, S. M.; Ruble, C. A. Antimicrob. Agents Chemother. 1993, 37, $1086-1094$. 
(19) Appendino, G.; Gibbons, S.; Giana, A.; Pagani, A.; Grassi, G.; Stavri, M.; Smith, E.; Rahman, M. M. J. Nat. Prod. 2008, 71, 1427-1430.

(20) Coqueiro, A.; Regasini L. O.; Stapleton, P.; Bolzani, V. S. Gibbons, S. J. Nat. Prod. 2014, 77, 1972-1975.

(21) Gibbons, S.; Udo, E. E. Phytother. Res. 2000, 14, 139-140.

(22) Wang, W.; Zeng, Y. H.; Osman, K.; Shinde, K.; Rahman, M.; Gibbons, S.; Mu, Q. J. Nat. Prod. 2010, 73, 1815-1820.

(23) Akgul, D. S.; Mirik, M. J. Plant Pathol. 2008, 90, 29-34.

(24) Kim, W. G.; Cho W. D.; Lee Y. H. Plant Pathol. J. 1992, 8, 213-215.

(25) Islam, M. T.; Croll, D.; Gladieux P.; Soanes, D. M.; Persoons, A.; Bhattacharjee, P.; Hossain, M. S.; Gupta, D. R., Rahman, M. M.; Mahboob, M. M.; Cook, N.; Salam, M. U.; Surovy, M. Z.; Sancho, V. B.; Maciel, J. L. N.; NhaniJunior, A.; Castroagudin, V. L.; Reges, J. T. D, A.; Ceresini, P. C.; Ravel S.; Kellner R.; Fournier E.; Tharreau, D.; Lebrun, M. H.; McDonald, B. A.; Stitt, T.; Swan, D.; Talbot, N. J.; Saunders, D. G. O.; Win, J.; Kamoun, S. BMC Biol. 2016, 14, 84-95.

(26) Rahman, M.; Rahman, M. M.; Deb, S. C.; Alam, M. S.; Alam, M. J.; Islam, M. T. Sci. Rep. 2017, 7, 3747.

(27) Rahman, M. M.; Garvey, M.; Piddock, L. J. V.; Gibbons, S. Phytother. Res. 2008, 22, $1356-1360$.

(28) Balouiri, M.; Sadiki, M.; Ibnsouda, S. K. J. Pharm. Anal. 2016, 6, 71-79.

(29) Tareq, F. S.; Lee, M. A; Lee, H. S.; Lee, Y. J.; Lee, J. S.; Hasan, C. M.; Islam, M. T.; Shin, H. J. J. Agric. Food Chem. 2014, 62, 5565-5572.

(30) Skehan, P.; Storeng, R.; Scudiero, D.; Monks, A.; McMahon, J.; Vistica, D.; Warren, J. T.; Bokesch, H.; Kenney, S.; Boyed. M. R. J. Natl. Cancer Inst. 1990, 82, 1107-1112. (31) Vichai, V.; Kirtikara, K. Nat. Protoc. 2006, 1, 1112-1116. 


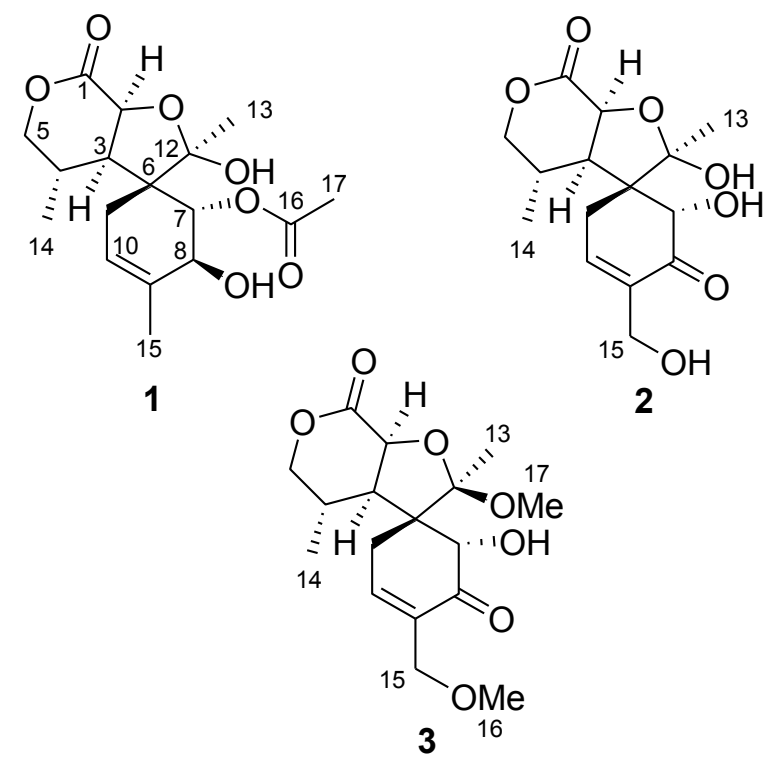

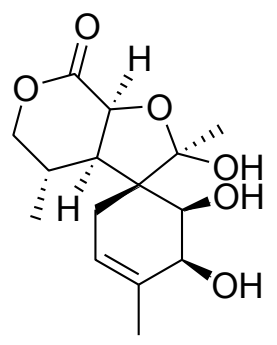

4

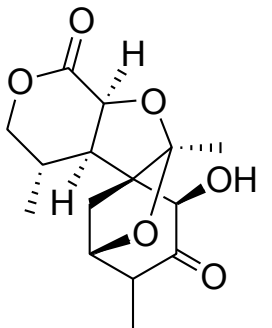

8

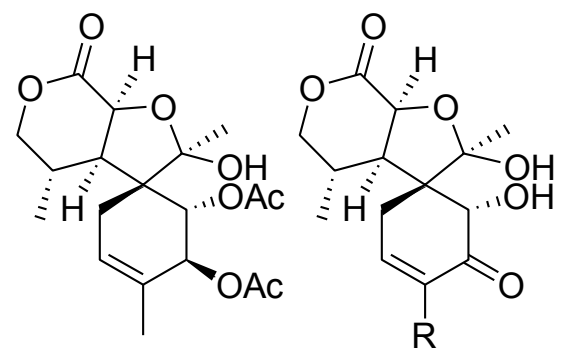

5

6: $\mathrm{R}=\mathrm{Me}$

7: $\mathrm{R}=\mathrm{CH}_{2} \mathrm{OMe}$<smiles>[R][C@H]1C(=O)OC[C@H](C)[C@H]1c1ccc(C)c(O)c1O</smiles>

9: $\mathrm{R}=\mathrm{H}$

10: $R=A c$ 


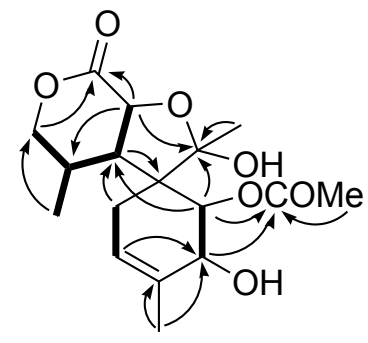

1

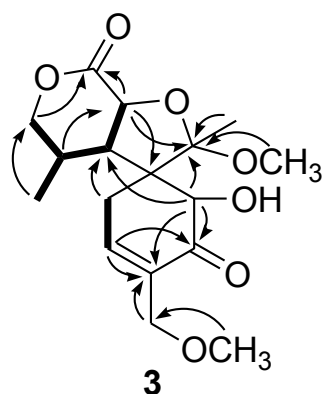

$\frown \mathrm{HMBC}$

COSY
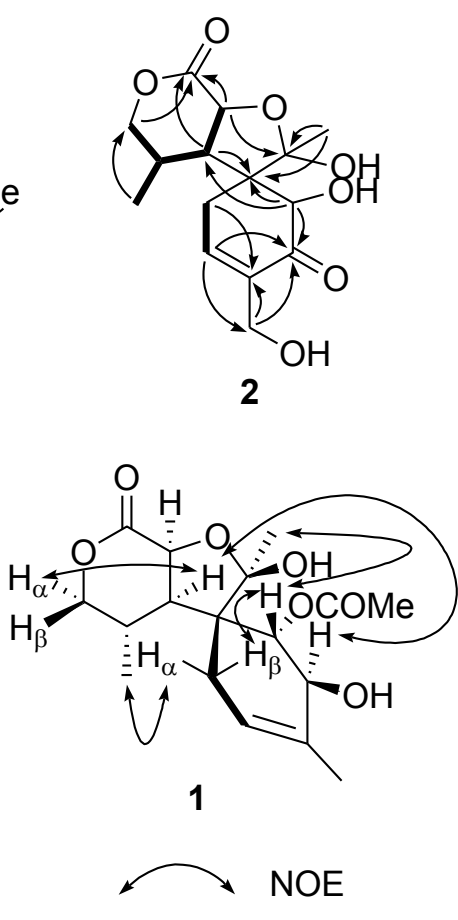

Figure 1. COSY, key HMBC, and key NOE correlations for 1-3. 
Table 1. ${ }^{1} \mathrm{H}$ NMR $(600.22 \mathrm{MHz}, 300 \mathrm{~K})$ and ${ }^{13} \mathrm{C}$ NMR $(151.91 \mathrm{MHz}, 300 \mathrm{~K})$ Data and ROESY Correlations for Compounds 1-3.

\begin{tabular}{|c|c|c|c|c|c|c|c|c|c|}
\hline \multicolumn{4}{|c|}{${ }^{a}$ 8-deacetylcyclocalopin B (1) } & \multicolumn{3}{|c|}{${ }^{b}$ cyclocalopin A-15-ol (2) } & \multicolumn{3}{|c|}{${ }^{a} 12,15$-dimethoxycyclocalopin A (3) } \\
\hline no. & $\delta_{\mathrm{C}}$, type & $\delta_{\mathrm{H}}(J$ in $\mathrm{Hz})$ & NOESY & $\delta_{\mathrm{C}}$, type & $\delta_{\mathrm{H}}(J$ in $\mathrm{Hz})$ & ${ }^{a} \mathrm{ROESY}$ & $\delta_{\mathrm{C}}$, type & $\delta_{\mathrm{H}}(J$ in $\mathrm{Hz})$ & ROESY \\
\hline 1 & $176.0, \mathrm{C}$ & & & 173.2, C & & & 174.6, C & & \\
\hline 2 & $73.5, \mathrm{CH}$ & $4.89(\mathrm{~d}, 10.5)$ & $3,5 \alpha, 17$ & $73.8, \mathrm{CH}$ & $4.56,(\mathrm{~d}, 10.0)$ & $3,5 \alpha$ & $73.3, \mathrm{CH}$ & $4.74(\mathrm{~d}, 10.3)$ & $3,5 \alpha$ \\
\hline 3 & $47.1, \mathrm{CH}$ & $\begin{array}{l}2.77(\mathrm{dd}, 10.5 \\
10.5)\end{array}$ & $2,5 \alpha, 8,14$ & $46.6, \mathrm{CH}$ & $\begin{array}{l}2.19(\mathrm{dd}, 10.0 \\
10.0)\end{array}$ & $2,5 \alpha, 14$ & $45.4, \mathrm{CH}$ & $\begin{array}{l}2.24(\mathrm{dd}, 10.3 \\
10.3)\end{array}$ & $2,5 \alpha, 14$ \\
\hline 4 & $30.3, \mathrm{CH}$ & $2.23(\mathrm{~m})$ & $5 \beta, 14$ & $30.8, \mathrm{CH}$ & $2.21(\mathrm{~m})$ & $5 \beta, 11 \alpha, 14$ & $29.6, \mathrm{CH}$ & $2.21(\mathrm{~m})$ & $5 \beta, 11 \alpha, 14$ \\
\hline $5 \alpha$ & $72.9, \mathrm{CH}_{2}$ & $\begin{array}{l}4.05(\mathrm{dd}, 11.0, \\
11.0)\end{array}$ & $3,5 \beta, 14$ & $72.5, \mathrm{CH}_{2}$ & $\begin{array}{l}3.82(\mathrm{dd}, 11.0 \\
11.0)\end{array}$ & $2,3,5 \beta, 14$ & $72.6, \mathrm{CH}_{2}$ & $\begin{array}{l}4.00(\mathrm{dd}, 11.2, \\
11.2)\end{array}$ & $2,3,5 \beta, 14$ \\
\hline $5 \beta$ & & $4.21(\mathrm{~m})$ & $4,5 \alpha, 14$ & & $\begin{array}{l}4.07(\mathrm{dd}, 11.0 \text {, } \\
1.6)\end{array}$ & $4,5 \alpha, 14$ & & $\begin{array}{l}4.18(\mathrm{dd}, 11.2 \text {, } \\
3.2)\end{array}$ & $4,5 \alpha, 14$ \\
\hline 6 & $52.9, \mathrm{C}$ & & & $56.5, \mathrm{C}$ & & & $56.7, \mathrm{C}$ & & \\
\hline 7 & $77.5, \mathrm{CH}$ & $5.07(\mathrm{~d}, 9.4)$ & $8,11 \beta, 13$ & $76.3, \mathrm{CH}$ & $4.29(\mathrm{~s})$ & $11 \beta, 13$ & $76.2, \mathrm{CH}$ & $4.63(\mathrm{~s})$ & $11 \beta, 13$ \\
\hline 8 & $71.9, \mathrm{CH}$ & $4.22(\mathrm{~d}, 9.4)$ & $3,7,15$ & 199.3, C & & & $200.4, \mathrm{C}$ & & \\
\hline 9 & 133.3, C & & & 136.1, C & & & $132.4, \mathrm{C}$ & & \\
\hline 10 & $123.1, \mathrm{CH}$ & $5.58(\mathrm{~m})$ & $11 \alpha, 11 \beta, 14,15$ & $145.9, \mathrm{CH}$ & $6.96(\mathrm{~m})$ & $11 \alpha, 11 \beta, 15$ & $150.6, \mathrm{CH}$ & $7.18(\mathrm{~m})$ & $\begin{array}{l}11 \alpha, 11 \beta, 15 \alpha \\
15 \beta\end{array}$ \\
\hline $11 \alpha$ & $27.2, \mathrm{CH}_{2}$ & $2.32(\mathrm{dm}, 20.2)$ & $10,11 \beta, 14$ & $28.0, \mathrm{CH}_{2}$ & $\begin{array}{l}2.78(\mathrm{dd}, 21.3 \\
5.3)\end{array}$ & $4,10,11 \beta,(14)$ & $27.8, \mathrm{CH}_{2}$ & $\begin{array}{l}2.85(\mathrm{dd}, 21.1 \text {, } \\
6.2)\end{array}$ & $4,10,11 \beta, 14$ \\
\hline $11 \beta$ & & $2.18(\mathrm{dm}, 20.2)$ & $7,10,11 \alpha, 13$ & & $2.55(\mathrm{dm}, 21.3)$ & $7,10,11 \alpha, 13$ & & $2.69(\mathrm{dm}, 21.1)$ & $7,10,11 \alpha, 13$ \\
\hline 12 & 108.3, C & & & 107.6, C & & & $110.9, \mathrm{C}$ & & \\
\hline 13 & $19.5, \mathrm{CH}_{3}$ & $1.45(\mathrm{~s})$ & $7,11 \beta, 15$ & 21.6, $\mathrm{CH}_{3}$ & $1.61(\mathrm{~s})$ & $7,11 \beta$ & $13.9, \mathrm{CH}_{3}$ & $1.55(\mathrm{~s})$ & $7,11 \beta, 17$ \\
\hline 14 & $14.6, \mathrm{CH}_{3}$ & $0.92(\mathrm{~d}, 6.5)$ & $\begin{array}{l}3,4,5 \alpha, 5 \beta, 10 \\
11 \alpha\end{array}$ & $16.8, \mathrm{CH}_{3}$ & $0.77(\mathrm{~d}, 6.0)$ & $\begin{array}{l}3,4,5 \alpha, 5 \beta \\
(11 \alpha)\end{array}$ & $15.5, \mathrm{CH}_{3}$ & $0.77(\mathrm{~d}, 6.5)$ & $\begin{array}{l}3,4,5 \alpha, 5 \beta \\
(11 \alpha)\end{array}$ \\
\hline 15 & $17.5, \mathrm{CH}_{3}$ & $1.74(\mathrm{~s})$ & 8,10 & $60.2, \mathrm{CH}_{2}$ & $4.30(\mathrm{~m})$ & 10 & $68.6, \mathrm{CH}_{2}$ & $\begin{array}{l}4.08(\mathrm{~d}, 12.3) \\
4.24(\mathrm{~d}, 12.3)\end{array}$ & $\begin{array}{l}10,15 \beta, 16 \\
10,15 \alpha, 16\end{array}$ \\
\hline 16 & 173.9, C & & & & & & $57.7, \mathrm{OCH}_{3}$ & $3.36(\mathrm{~s})$ & $15 \alpha, 15 \beta$ \\
\hline 17 & $21.1, \mathrm{CH}_{3}$ & $2.14(\mathrm{~s})$ & 2 & & & & $48.4, \mathrm{OCH}_{3}$ & $3.17(\mathrm{~s})$ & 13 \\
\hline
\end{tabular}

Chemical shifts and coupling constants of $\mathbf{1}-\mathbf{3}$ were determined in ${ }^{a} \mathrm{D}_{2} \mathrm{O}$ and ${ }^{b} \mathrm{CDCl}_{3}+\mathrm{CD}_{3} \mathrm{OD}(10: 1)$, respectively. Assignments were based on 2D NMR including $\mathrm{HSQC}$ and HMBC. Coupling constants were measured using ${ }^{1} \mathrm{H}$ NMR in combination with phase-sensitive COSY correlations. Well-resolved couplings are expressed with coupling patterns and coupling constants in $\operatorname{Hertz}(\mathrm{Hz})$ in parentheses. 
Table 2. Anti-Staphylococcal Activity of the Compounds 1-10.

\begin{tabular}{cccccc}
\hline Compound & \multicolumn{5}{c}{ Microorganism, MIC $[\boldsymbol{\mu g} / \mathbf{m L}]$} \\
\cline { 2 - 6 } & ATCC & XU212 & SA-1199B & RN4220 & EMRSA-15 \\
& 25923 & & & & \\
\hline $\mathbf{1}$ & 16 & 32 & 16 & ND & 32 \\
$\mathbf{2}$ & 64 & 64 & 128 & ND & 128 \\
$\mathbf{3}$ & 128 & 128 & 256 & ND & 256 \\
$\mathbf{4}$ & 32 & ND & 64 & ND & 64 \\
$\mathbf{5}$ & ND & 64 & 64 & ND & ND \\
$\mathbf{6}$ & 32 & ND & 64 & ND & 64 \\
$\mathbf{7}$ & 64 & 128 & 64 & ND & 128 \\
$\mathbf{8}$ & 64 & 64 & 128 & ND & 64 \\
$\mathbf{9}$ & 64 & 128 & 128 & ND & 128 \\
$\mathbf{1 0}$ & ND & 64 & 128 & ND & 64 \\
p. c. & 32 & 32 & 64 & ND & 32 \\
\hline
\end{tabular}

p. c. $=$ Positive control (Norfloxacin). ND = Not detectable. 


\section{Table of Contents Graphic}

\section{Anti-Staphylococcal Calopins from Fruiting Bodies of Caloboletus radicans}

Fakir Shahidullah Tareq, Choudhury Mahmood Hasan, M. Mukhlesur Rahman, Mohd Mukrish Mohd Hanafi, Lucio Colombi Ciacchi, Monika Michaelis, Tilmann Harder, Jan Tebben, Md. Tofazzal Islam, Peter Spiteller*
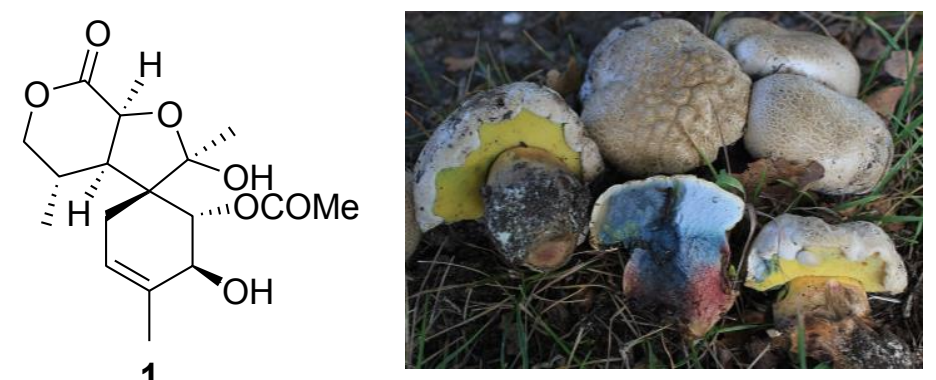